\title{
Protective Effects of Zeolite (Clinoptilolite) on Copper Toxicity in Tilapia (Oreochromis niloticus)
}

\author{
Mustafa TÜRKMEN ${ }^{1 *}$ Zühtü Mete DİNLER ${ }^{2}$ \\ ${ }^{\text {I} G i r e s u n ~ U n i v e r s i t y, ~ D e p a r t m e n t ~ o f ~ B i o l o g y, ~ 281000, ~ G i r e s u n, ~ T u ̈ r k i y e ~}$

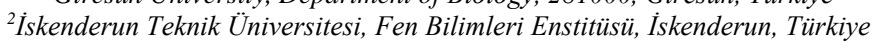

How to cite: Türkmen, M. \& Dinler, Z.M. (2021). Protective Effects of Zeolite (Clinoptilolite) on Copper Toxicity in Tilapia (Oreochromis niloticus). J. Anatolian Env. and Anim. Sciences, 6(2), 188-194.

Atıf yapmak için: Türkmen, M. \& Dinler, Z.M. (2021). Zeolitin (Clinoptilolite) Tilapiya (Oreochromis niloticus)'da Bakır Toksisitesi Üzerine Koruyucu Etkisi. Anadolu Çev. ve Hay. Dergisi, 6(2), 188-194.

https://orcid.org/0000-0001-6700-5947 (iD): https://orcid.org/0000-0002-3963-2510
*Corresponding author's: Mustafa TÜRKMEN

Giresun University, Department of Biology, 281000, Giresun, Türkiye 凶: mturkmen65@hotmail.com

\begin{abstract}
In this study, the protective effects of zeolite added to water on tilapias exposed to sublethal concentration of copper was investigated. Treatment groups were copper, copper+zeolite, zeolite, and control. After 90 days trial, weight-length, copper accumulation in the liver, and muscle protein ratios of fishes were measured. BUN, LDH, glucose, cholesterol, and triglyceride parameters of blood were also measured by taken monthly blood samples. The highest increase in weight was observed in zeolite treatment by $68.5 \%$. Copper accumulations in the liver were 12.6; $10.8 ; 1.27$ and $1.33 \mathrm{ppm}$ for the copper, copper + zeolite, zeolite, and the control groups, respectively. Although $\mathrm{BUN}, \mathrm{LDH}$, cholesterol of copper + zeolite treatment were lower, triglyceride and glucose levels were higher compared to the control group $(p<0.05)$. Muscle protein ratios decreased in all treatments at the end of the study. According to these results, zeolite treatment against copper toxicity in tilapia would be recommended.
\end{abstract}

Keywords: Blood parameters, Clinoptilolite, natural zeolite, Oreochromis niloticus, tilapia.

\section{Zeolitin (Clinoptilolite) Tilapiya (Oreochromis niloticus)'da Bakır Toksisitesi Üzerine Koruyucu Etkisi}

*Sorumlu yazar:

Mustafa TÜRKMEN

Giresun Üniversitesi, Biyoloji Bölümü,

28100, Giresun, Türkiye

凶: mturkmen65@hotmail.com
Öz: Bu çalışmada bakırın sublethal düzeyine maruz kalmış Tilapyalar üzerine suya ilave edilen zeolitin koruyucu etkisi araştırılmıştır. Muameleler; bakır, bakır+zeolit, zeolit ve kontroldür. Doksan günlük deneme sonunda balıkların ağırlık ve boyca gelişimi, karaciğerde bakır birikimi ve kas protein oranları ölçülmüştür. Ayrıca her ay yapılan kan örneklemelerinde BUN, LDH, glikoz, kolesterol, trigliserit parametreleri de ölçülmüştür. Ağılık değişimi en yüksek \% 68,5 oranı ile zeolit muamelesinde bulunmuştur. Karaciğer bakır birikimleri bakır, bakır + zeolit, zeolit ve kontrol muameleleri için sırasıyla 12,$6 ; 10,8 ; 1,27 ; 1,33 \mathrm{ppm}$ olarak bulunup, istatistiksel olarak aralarındaki fark önemlidir $(\mathrm{p}<0,05)$. Deneme sonunda bakır + zeolit muamelesinin kan parametreleri, kontrol muamelesi ile karşılaştırıldığında, BUN, LDH, kolesterol seviyesi düşük bulunmuştur. Buna karşın trigliserit ve glikoz seviyesi yüksek bulunmuştur. Başlangıç protein oranına göre, deneme sonundaki kas protein oranı düşük bulunmuştur. Bu sonuçlara göre, Tilapya'da bakır toksisitesine karşı zeolit uygulanması önerilebilir.

Anahtar kelimeler: Clinoptilolit, doğal zeolit, kan parametreleri, Oreochromis niloticus, tilapya. 


\section{INTRODUCTION}

Copper sulfate can be used in aquaculture for algae control in ponds, including high-build and filamentous algae such as Chara. Besides, it is used for the control of external parasites such as Ichthyophthirius multifiliis. If the environment alkalinity is lower than 50 ppm or higher than $250 \mathrm{ppm}$, copper sulphate should not be applied (Boyd \& Tucker, 1998; Watson \& Yanong, 2002). Car graveyards, cooling water discharges, coppercontaining pesticides, water distribution pipes, brake linings of vehicles such as cars, trucks, buses and trucks, metal plating and processing industry, refineries, roofing materials and mine smelting enterprises are reported as sources of copper contamination in the environment (Fialkowski \& Newman, 1998). Soluble copper compounds from agricultural runoff can be extremely harmful. When they enter aquatic ecosystems, they usually bind to particles in the water in about a day and thus pose less of a threat to the environment depending on the environmental conditions. It is reported that copper is not carcinogenic (ATSDR, 2003).

Evaluation of blood parameters in animals is a conventional method and an important finding. With this simple technique, it is possible to make reliable decisions about the physiological situation of the animal. Many factors are affecting the blood parameters in fish. These may be environmental (temperature, photoperiod, density, salinity), physiological (sexual maturation cycle, age, gender, nutrition), and social (social hierarchy) factors. Monitoring of blood chemistry in aquaculture practices has been reported to be closely linked to water quality, disease or exposure to toxic substances (Başusta, 2005; Chen et al., 2003; Türkmen et al., 2000). Cholesterol, a type of lipid, is the most important member of the sterols found in animal tissues. It is found as free and combined with fatty acids in all cells and blood of fish. It has been found that serum cholesterol level in fish varies according to gender. If its amount in the blood is high, it can cause cardiovascular diseases. Fish needs a certain amount of to maintain their vital functions (Akyurt, 2004). It reduces the blood cholesterol level of copper, chromium, calcium, vitamin C and E. Salts increase the cholesterol level in the blood (Alfin-Slater \& Howton, 1993). There may be an increase in serum BUN levels of fish that add copper to their diet. This increase causes deterioration and incomplete development of gill epithelial cells and should be understood as a clinical explanation of the impairment in respiratory and excretory balance (Cicik, 2003).

Although zeolite studies have continued intensively in the last 50 years, the use of natural zeolite has gained importance in recent years. Natural zeolites remove cations from water by ion exchange (Türkman et al., 2001). Clinoptilolite has a very high selectivity against heavy metal ions such as $\mathrm{Pb}^{+2}, \mathrm{Zn}^{+2}, \mathrm{Cd}^{+2}, \mathrm{Ni}^{+2}, \mathrm{Cu}^{+2}, \mathrm{Fe}^{+2}$ and $\mathrm{Mn}^{+2}$ (Park, 2000; Türkman et al., 2001). It is known that heavy metal pollution causes stress in fish and stressrelated changes occur in metabolism. Glycogen stored in the muscle and liver tissues of fish is used to meet the urgent energy requirement under stress (Cicik, 2003; Akyurt, 2004). There are many studies on metal toxicity and the effect of zeolite on blood parameters in fish (Frrat \& Şahin İnandı, 2016; Mutlu et al., 2016; Oğuztürk et al., 2018; Çoğun \& Kargın, 2019; Çoğun \& Kargın, 2020; Chen et al., 2020). In this study, it was aimed to investigate the protective effect of zeolite in the water on tilapia exposed to the sub-lethal level of copper sulfate. Due to the high ion exchange capacity of the zeolite, the effects of copper on the accumulation of fish liver and some blood parameters were studied.

\section{MATERIAL AND METHODS}

Tilapia (Oreochromis niloticus) was used as a fish material in the study. Until the trial begins, fish were fed with a commercial feed in 200x50x50 cm polyethylene tanks. Later, it was stocked as 32 pieces in each aquarium. This study was carried out in Mustafa Kemal University Faculty of Fisheries, Aquarium Unit. Aquariums were 80x40x40 cm in size and 128 liters, 90 liters of this volume have been used. The water depth in the aquariums is planned as 28.1 centimeters. The aeration system and the heaters in aquariums were operated continuously. Tap water was used in the experiment. To remove wastes from aquariums, $2 / 3$ of the aquarium water volume was siphoned every 3 days. Then with the same amount of water, the amounts of $\mathrm{CuSO}_{4} \cdot 5 \mathrm{H}_{2} \mathrm{O}$ and zeolite contained in the water calculated and returned to the aquarium. Experimental groups and their contents were given in Table 1.

Table 1. Experimental groups.

\begin{tabular}{ccccc}
\hline & \multicolumn{4}{c}{ Experimental groups } \\
\cline { 2 - 5 } & $\mathrm{Cu}(\mathrm{mg} / \mathrm{L})$ & $\mathrm{Cu}+$ Zeolite $(\mathrm{mg} / \mathrm{L})$ & Zeolite $\mathrm{mg} / \mathrm{L})$ & Control \\
\hline Contents & 1.5 & $1.5+50$ & 50 & ---- \\
\hline
\end{tabular}

Three fish were taken from each aquarium every 30 days and a repeat has been created. The trial was carried out in one-month periods for 3 months ( 3 terms). Fish were fed with commercial feed containing 30\% crude protein and $2600 \mathrm{kcal} / \mathrm{kg}$ metabolic energy and they were fed with $3 \%$ of their live weight in three meals a day. Fish was anesthetized with 1/20000 concentration Quinaldine and blood was drawn from the tail area. Post-anesthetized, $3 \mathrm{ml}$ blood from the tail parts of fish was taken into sterile tubes 
containing EDTA $(2.5 \mathrm{mg} / \mathrm{ml})$. Samples were collected individually into plastic vials and the serum separated by centrifugation at 4,000 rpm for $10 \mathrm{~min}$, was then processed immediately by an automated cell analyzer (MerckMega/Toshiba-Japan) to analyze blood cholesterol, glucose, triglycerides, BUN (blood urea nitrogen) and LDH (lactate dehydrogenase) levels (Bricknell et al., 1999).

Liver samples of the fish from which blood samples were taken were also taken and burned in the ash furnace (Yazkan et al., 2002), ash samples were treated with acid (Ünlü \& Gümgüm, 1993), and were filtered and completed to $25 \mathrm{ml}$ with deionized water (Türkmen \& Ögüutçü, 2020). Liver samples ready for analysis were read at $324.8 \mathrm{~nm}$ in the ICP device and expressed as $\mathrm{mg} / \mathrm{kg}$ dry weight. Crude protein determination in muscle samples of fish was analyzed by the Kjeldahl method (Duru, 2004). To test the differences between species, one- way ANOVA was performed (SPSS 21.0). A significance level was set to 0.05 for all statistical analyses.

\section{RESULT AND DISCUSSION}

The length, weight, liver weight and muscle tissue protein ratios of the fish according to the experimental groups are presented in Table 2. No death was observed during the trial period. It is seen that there is no difference between the groups in terms of initial length and weight of the samples $(p>0.05)$. At the end of the experiment, the lowest value in fish weight was in the control group with $22.2 \mathrm{~g} / \mathrm{fish}$, the highest value was found in the $\mathrm{Cu}+$ zeolite group with $26.6 \mathrm{~g} /$ fish (Table 2).

Table 2. The mean values of the length, weight, liver weight and muscle tissue protein ratios of the fish according to the experimental groups.

\begin{tabular}{lccccc}
\hline \multicolumn{1}{c}{ Parameters } & $\mathrm{Cu}$ & $\mathrm{Cu}+$ Zeolite & Zeolite & Control & $\mathrm{p}$ \\
\cline { 2 - 6 } & $16.7 \pm 0.5$ & $16.6 \pm 1.0$ & $14.3 \pm 0.5$ & $16.2 \pm 1.4$ & 0.28 \\
\hline Initial weight $(\mathrm{g})$ & $24.6 \pm 4.8$ & $26.6 \pm 3.7$ & $24.1 \pm 3.6$ & $22.2 \pm 5.5$ & 0.91 \\
$90^{\text {th }}$ day weight $(\mathrm{g})$ & $10.0 \pm 0.1$ & $10.0 \pm 0.1$ & $9.40 \pm 0.1$ & $9.53 \pm 0.3$ & 0.10 \\
Initial length $(\mathrm{cm})$ & $11.6 \pm 0.6$ & $11.8 \pm 0.6$ & $11.3 \pm 0.7$ & $11.3 \pm 0.7$ & 0.94 \\
$90^{\text {th }}$ day length $(\mathrm{cm})$ & $0.15 \pm 0.0$ & $0.20 \pm 0.0$ & $0.13 \pm 0.0$ & $0.15 \pm 0.0$ & 0.19 \\
$\begin{array}{l}\text { Initial liver weight }(\mathrm{g}) \\
90^{\text {th }} \text { day liver weight }(\mathrm{g})\end{array}$ & $0.51 \pm 0.1$ & $0.48 \pm 0.1$ & $0.60 \pm 0.1$ & $0.61 \pm 0.0$ & 0.80 \\
$\begin{array}{l}\text { Initial muscle tissue } \\
\text { protein ratio (\%) }\end{array}$ & $12.4 \pm 1.6$ & $10.2 \pm 1.2$ & $10.6 \pm 1.1$ & $11.2 \pm 0.2$ & 0.52 \\
$\begin{array}{l}\text { 90 } \\
\text { protein ratio }(\%)\end{array}$ & $8.93 \pm 0.6$ & $9.11 \pm 0.5$ & $7.95 \pm 0.2$ & $9.55 \pm 0.4$ & 0.24 \\
\hline
\end{tabular}

The increases in the experimental groups are given in Table 3. Maximum live weight gain $10 \mathrm{~g} \mathrm{fish}^{-1}$ with copper + zeolite treatment, the lowest body weight gain in the control treatment with $6.0 \mathrm{~g} \mathrm{fish}^{-1}$ was found. Besides, at the end of the trial, the differences between the lengths and weights of the treatment groups were found to be statistically insignificant $(p>0.05)$. Among the treatments, the lowest length gain was $1.60 \mathrm{~cm}$ in copper treatment, and the highest length gain was $1.90 \mathrm{~cm}$ in the zeolite treatment. Both body weight and liver weight increased at the end of the trial. The highest increase in liver weight gain was determined in the zeolite group with $0.47 \mathrm{~g} \mathrm{fish}^{-1}$ and the lowest in the copper + zeolite group with $0.28 \mathrm{~g} \mathrm{fish}^{-1}$. At the end of the trial, a decrease in muscle tissue protein level was observed in all groups. The highest change in length was observed in the zeolite group with $20.2 \%$ and the lowest in the copper group with $16.0 \%$ (Table 3). The maximum weight change was observed in the zeolite group with $68.5 \%$ and the least in the control group with $37.0 \%$. Although the percentage of weight change of fish exposed to copper only is higher than the control treatment, it is lower than the zeolite and copper + zeolite treatments. Also, the copper + zeolite treatment showed an improvement close to only the zeolite treatment, with a $60.2 \%$ weight gain change. The least change in protein level occurred in the copper + zeolite treatment with a decrease of $1.04 \%$, and the most change in the copper treatment with a decrease of $3.44 \%$.

Table 3. Changes in trial groups after 90 days of study.

\begin{tabular}{lcccc}
\hline \multirow{2}{*}{ Parameters } & \multicolumn{4}{c}{ Experimental groups } \\
\cline { 2 - 5 } & $\mathrm{Cu}$ & $\mathrm{Cu}+$ Zeolite & Zeolite & Control \\
\hline Body weight gain (g) & 7.90 & 10.0 & 9.80 & 6.00 \\
Length gain (cm) & 1.60 & 1.80 & 1.90 & 1.77 \\
Liver weight gain (g) & 0.36 & 0.28 & 0.47 & 0.46 \\
Muscle protein ratio change (\%) & -3.44 & -1.04 & -2.67 & -1.62 \\
Weight change (\%) & 47.3 & 60.2 & 68.5 & 37.0 \\
Length change (\%) & 16.0 & 18.0 & 20.2 & 18.6 \\
\hline
\end{tabular}

At the end of the experiment, protein ratios were found as $8.93 \%$ in copper treatment, $9.11 \%$ in copper + zeolite treatment, $7.95 \%$ in zeolite treatment, and $9.55 \%$ in the control treatment. In a trial conducted on fish exposed to lethal doses of copper, the carcass protein ratios of the groups treated with $0.15 \mathrm{ppm}, 0.30 \mathrm{ppm}, 0.50 \mathrm{ppm}$ and 0 ppm copper in water were reported as $14.94 ; 14.95 ; 14.82$ and 15.18. The researchers reported that a decrease in protein due to an increase in copper concentration in water at the end of the experiment was statistically significant for the carcass protein ratio (Al1 et al., 2003). Proportions of protein obtained in this study were lower than the values reported by Alı et al., (2003). The amount of crude protein ratio in fish meat varies according to the type, age, sex, feeding environment, breeding and migration seasons of the fish. The amount of protein in fish meat varies between 15-24\% (Gülyavuz \& Ünlüsayın, 1999).

Copper Accumulation: Copper accumulation in the liver levels obtained at the end of the trial according to the experimental groups were presented in Table 4. The lowest copper accumulation was observed in the zeolite group (50 mg/L zeolite) and similar to the control group, but statistically different from the copper and copper + zeolite groups $(\mathrm{p}<0.05)$. On the other hand, the highest accumulation was observed in the group exposed to 1.5 $\mathrm{mg} / \mathrm{L} \mathrm{Cu}$. Heavy metals increased the total protein 
concentration in tissues with high metabolic activity. It has been reported that while the total protein ratio of the liver tissue increases in O.niloticus exposed to copper, the total protein ratio of the muscle tissue decreases (Kalay \& Erdem, 2003).

Table 4. Copper accumulation in the liver according to the experimental groups (ppm dry w.).

\begin{tabular}{lcccc}
\hline & \multicolumn{4}{c}{ Experimental groups } \\
\cline { 2 - 5 } Accumulation & $\mathrm{Cu}$ & $\mathrm{Cu}+$ Zeolite & Zeolite & Control \\
\hline & $12.6 \pm 2.87^{\mathrm{b}}$ & $10.8 \pm 5.27^{\mathrm{b}}$ & $1.27 \pm 0.39^{\mathrm{a}}$ & $1.33 \pm 0.13^{\mathrm{a}}$ \\
& $10,8 \pm 5,27^{\mathrm{b}}$ & & & \\
$1,27 \pm 0,39^{\mathrm{a}}$ & & & \\
& $1,33 \pm 0,13^{\mathrm{a}}$ & & \\
\hline
\end{tabular}

This situation was similar to our findings. In a study, the copper accumulation in the liver was reported as $16.27 \mathrm{ppm}, 24.41 \mathrm{ppm}, 38.34 \mathrm{ppm}$, and $10.92 \mathrm{ppm}$, respectively (Al1 et al., 2003). These reported values are different from our findings. This may be due to differences in water quality parameters ( $\mathrm{pH}$, alkalinity, and hardness), fish weights, copper exposure time, and copper concentrations added to the water. Water containing high levels of copper causes vomiting, diarrhea, nausea, and cramps. It accumulates mostly in the liver, kidney, stomach, lung, intestine, heart, brain and adrenal gland (ATSDR, 2003). Also; copper, an essential element for the enzyme system in fish, is toxic at high concentrations. Higher levels of copper in the water cause fish species to consume oxygen faster. It also binds to the structure of proteins containing histidine, cysteine and methionine, preventing them from fulfilling their functions. The primary target for copper in water is the fish's large surface area gills (Van Heerden et al., 2004).

In another study conducted to examine the effect of zeolite and copper on tilapia, $2.14 \mathrm{mg} / \mathrm{L}$ copper was added to the water. At the end of the $90^{\text {th }}$ day, liver copper accumulation was $8.63 \mathrm{ppm}$ in tilapia exposed only to copper, while it was observed that liver copper accumulation decreased significantly with increasing rates of zeolite. In the same study, it was also reported that copper ratios of tilapia exposed to copper and zeolite decreased significantly over time (James \& Sampath, 2003). This situation is similar to our findings. In a study conducted on carp fish, protection from lead toxicity was investigated by adding zeolite to the water, and no statistically significant difference was found between treatments in liver weight and weight gain at the end of the trial (Tepe et al., 2004). In our study, the addition of zeolite caused a decrease in liver copper accumulation.

Blood parameters: Three-period analyses results of blood parameters according to the experimental groups are given in Table 5. Blood Urea Nitrogen, LDH, and glucose levels generally showed an increasing trend in all experimental groups depending on the time. On the other hand, cholesterol levels showed an increase in the copper and copper + zeolite group, and a decrease in the zeolite group, depending on time. BUN was the lowest in all periods in the control group and the highest in the $\mathrm{Cu}+$ zeolite group on the $90^{\text {th }}$ day. $\mathrm{LDH}$ was lowest in the control group on the 30th day and the highest in the zeolite group on the $90^{\text {th }}$ day. The glucose levels were the lowest in the $\mathrm{Cu}+$ zeolite group on the $30^{\text {th }}$ day and the highest on the $90^{\text {th }}$ day in the zeolite group. Cholesterol levels were lowest in the control group on the $30^{\text {th }}$ day and the highest on the $90^{\text {th }}$ day in the zeolite group. Triglyceride levels were the lowest in the copper + zeolite group and the highest in the copper group on the $90^{\text {th }}$ day.

Table 5. Results of blood parameters according to trial periods and groups.

\begin{tabular}{|c|c|c|c|c|}
\hline \multirow{2}{*}{$\begin{array}{l}\text { Blood } \\
\text { Parameters/Periods }\end{array}$} & \multicolumn{4}{|c|}{ Experimental groups } \\
\hline & $\mathrm{Cu}$ & $\mathrm{Cu}+$ Zeolite & Zeolite & Control \\
\hline \multicolumn{5}{|l|}{ BUN $\left(\mathrm{mg} \mathrm{dl}^{-1}\right)$} \\
\hline $30^{\text {th }}$ day & $2.30 \pm 0.0^{x}$ & $2.40 \pm 0.0^{x}$ & $1.90 \pm 0.0^{\mathrm{x}}$ & $2.10 \pm 0.0^{\mathrm{x}}$ \\
\hline $60^{\text {th }}$ day & $2.60 \pm 0.0^{x}$ & $2.70 \pm 0.0^{x}$ & $2.00 \pm 0.0^{\mathrm{x}}$ & $2.10 \pm 0.0^{x}$ \\
\hline $90^{\text {th }}$ day & $2.80 \pm 0.0^{x}$ & $2.90 \pm 0.0^{x}$ & $2.20 \pm 0.0^{\mathrm{x}}$ & $2.10 \pm 0.0^{x}$ \\
\hline \multicolumn{5}{|l|}{$\operatorname{LDH}\left(\mu \mathrm{g} \mathrm{dl}^{-1}\right)$} \\
\hline $30^{\text {th }}$ day & $864 \pm 4.05^{x}$ & $893 \pm 1.76^{x}$ & $1268 \pm 1.45^{\mathrm{x}}$ & $772 \pm 1.45^{x}$ \\
\hline $60^{\text {th }}$ day & $1102 \pm 1.76^{y}$ & $974 \pm 2.30^{y}$ & $1492 \pm 1.45^{y}$ & $795 \pm 1.45^{y}$ \\
\hline $90^{\text {th }}$ day & $1366 \pm 2.40^{2}$ & $1010 \pm .57^{z}$ & $1528 \pm 1.15^{x}$ & $800 \pm 0.88^{2}$ \\
\hline \multicolumn{5}{|l|}{ Glucose $\left(\mathrm{mg} \mathrm{dl}^{-1}\right)$} \\
\hline $30^{\text {th }}$ day & $122 \pm 0.67^{x}$ & $108 \pm 0.88^{x}$ & $160 \pm 1.16^{x}$ & $134 \pm 1.76^{x}$ \\
\hline $60^{\text {th }}$ day & $135 \pm 1.20^{y}$ & $129 \pm 0.88^{y}$ & $160 \pm 0.58^{x}$ & $137 \pm 1.16^{x}$ \\
\hline $90^{\text {th }}$ day & $148 \pm 0.88^{z}$ & $141 \pm 0.88^{2}$ & $162 \pm 0.57^{x}$ & $137 \pm 0.66^{x}$ \\
\hline \multicolumn{5}{|l|}{ Cholesterol $\left(\mathrm{mg} \mathrm{dl}^{-1}\right)$} \\
\hline $30^{\text {th }}$ day & $134 \pm 0.88^{z}$ & $122 \pm 1.45^{2}$ & $128 \pm 0.67^{x}$ & $95 \pm 0.88^{x}$ \\
\hline $60^{\text {th }}$ day & $123 \pm 0.88^{y}$ & $112 \pm 1.16^{y}$ & $138 \pm 0.58^{y}$ & $100 \pm 0.68^{y}$ \\
\hline $90^{\text {th }}$ day & $112 \pm 0.58^{x}$ & $100 \pm 0.58^{x}$ & $141 \pm 0.58^{z}$ & $98 \pm 0.58^{y}$ \\
\hline \multicolumn{5}{|l|}{ Triglyceride $\left(\mathrm{mg} \mathrm{dl}^{-1}\right)$} \\
\hline $30^{\text {th }}$ day & $59.67 \pm 2.60^{x}$ & $55.33 \pm 3.33^{x}$ & $56.33 \pm 2.73^{x}$ & $69.33 \pm 4.18$ \\
\hline $60^{\text {th }}$ day & $57.33 \pm 1.20^{x}$ & $62.00 \pm 1.15^{y}$ & $51.67 \pm 0.33^{x}$ & $59.67 \pm 0.88$ \\
\hline $90^{\text {th }}$ day & $73.00 \pm 0.58^{y}$ & $\underline{50.67 \pm 0.33^{x}}$ & $53.67 \pm 0.33^{x}$ & $59.00 \pm 0.58$ \\
\hline
\end{tabular}

The fact that all blood parameters are at the maximum level on the $90^{\text {th }}$ day can be explained by the stress that may be caused by the long-term retention of fish in aquariums. It has been reported that stress increases the blood glucose level significantly and the carbohydrate content of diets with different sources affects the blood glucose level (Yıldırım et al., 1999).

It is known that heavy metal pollution causes stress in fish and stress-related changes occur in metabolism. Stored in the muscle and liver tissues of fish, glycogen is used to meet the urgent energy requirement under stress. It has been reported that non-lethal concentrations of copper in fish such as trout (Oncorhynchus mykiss) and carp (Cyprinus carpio) decrease glycogen levels in muscle and liver tissues and increase blood glucose levels (Cicik, 2003). The blood parameters obtained by analyzing the blood samples taken from the fish on the 90th day of the experiment are given in Table 6. The differences between experimental groups were found to be statistically significant for all parameters $(\mathrm{p}<0.05)$. The control group was lower than the other groups for LDH and cholesterol. The lowest BUN levels 
were observed in the zeolite group and the highest in the copper + zeolite group.

Table 6. The blood parameters obtained according to the experimental groups on the $90^{\text {th }}$ day of the trial.

\begin{tabular}{|c|c|c|c|c|}
\hline \multirow[b]{2}{*}{ Blood Parameters } & \multicolumn{3}{|c|}{ Experimental groups } & \multirow[b]{2}{*}{ Control } \\
\hline & $\mathrm{Cu}$ & Cu+Zeolite & Zeolite & \\
\hline $\operatorname{BUN}\left(\mathrm{mg} \mathrm{dl}^{-1}\right)$ & $2.57 \pm 0.07^{\mathrm{b}}$ & $2.67 \pm 0.07^{\mathrm{b}}$ & $2.03 \pm 0.04^{\mathrm{a}}$ & $2.10 \pm 0.00^{\mathrm{a}}$ \\
\hline $\operatorname{LDH}\left(\mu \mathrm{g} \mathrm{dl}^{-1}\right)$ & $1111 \pm 72^{\circ}$ & $959 \pm 17^{\mathrm{b}}$ & $1429 \pm 40^{d}$ & $789 \pm 4.4^{\mathrm{a}}$ \\
\hline Glucose $\left(\mathrm{mg} \mathrm{dl}^{-1}\right)$ & $135 \pm 3.78^{b}$ & $126 \pm 4.73^{\mathrm{a}}$ & $160 \pm 0.44^{c}$ & $136 \pm 0.73^{b}$ \\
\hline Cholesterol $\left(\mathrm{mg} \mathrm{dl}^{-1}\right)$ & $123 \pm 3.15^{\mathrm{c}}$ & $111 \pm 3.23^{\mathrm{b}}$ & $136 \pm 2.04^{d}$ & $97.9 \pm 0.81^{\mathrm{a}}$ \\
\hline Triglyceride $\left(\mathrm{mg} \mathrm{dl}^{-1}\right)$ & $65.3 \pm 2.58^{\mathrm{b}}$ & $56.0 \pm 1.94^{\mathrm{a}}$ & $53.9 \pm 1.05^{\mathrm{a}}$ & $62.7 \pm 2.08^{b}$ \\
\hline
\end{tabular}

The highest levels of LDH, glucose and cholesterol were observed in only zeolite added group. On the other hand, the highest triglyceride level was observed in the copper added group and the lowest in the zeolite group. Triglyceride is the most common form of lipids stored in adipose tissue and is the main source of energy. Triglyceride is synthesized in the intestinal mucosa and liver by digestion and absorption of lipids in food content (Atamanalp et al., 2003).

In one study, blood cholesterol levels were reported as $104.5 \mathrm{mg}$ dl-1 for control, $239 \mathrm{mg}$ dl-1 for leadonly treatment, $171.5 \mathrm{mg}$ dl-1 for zeolite + lead, and 164.5 mg dl-1 for zeolite alone. However, it has been reported that lead alone treatment caused a statistically significant increase in LDH and cholesterol levels compared to the control treatment (Tepe et al., 2004).

This situation is similar to our study, and our findings for glucose and cholesterol were lower than Tepe et al., (2004) findings. In a study by Hussein et al. (1996) on Tilapias (O. niloticus) weighing an average of $38.46 \mathrm{~g}$, BUN, cholesterol, and glucose levels were reported as 8.41 $\mathrm{mg} \mathrm{dl}^{-1}, 161.3 \mathrm{mg} \mathrm{dl}^{-1}$, and $52.3 \mathrm{mg} \mathrm{dl}^{-1}$, respectively (Chen et al., 2003). The BUN and cholesterol levels of this study were high and the glucose level was low in our study.

In a study conducted on tilapias, glucose was found to be the lowest $52 \mathrm{mg} \mathrm{dl}^{-1}$, the highest $156 \mathrm{mg} \mathrm{dl}^{-1}$, the lowest cholesterol $162 \mathrm{mg} \mathrm{dl}^{-1}$, the highest $440 \mathrm{mg} \mathrm{dl}^{-1}$ and the BUN value of $2 \mathrm{mg} \mathrm{dl}^{-1}$ (Chen et al., 2003). When compared with the values of our study, glucose levels are consistent with the mentioned study. The cholesterol level was found to be lower than the study mentioned. The BUN level was found to be compatible with the control and zeolite treatments, higher than the copper and copper + zeolite treatment. Prolonged exposure to copper in tilapia fish may cause liver glycogen to be transported into blood glucose. Glucose, cholesterol, and BUN values indicate short-term exposure to copper, and low levels indicate long-term copper exposure (Straus, 2003). The findings of our trial point to long-term copper exposure. The most easily used carbohydrate by fish is glucose and the only sugar found in the blood (Hoşsu et al., 2001). Blood glucose is stored in the livers of fish as glycogen and converted into glucose when the organism needs it and fed into the blood (Başusta, 2005). With the breakdown of glucose, the energy needed to maintain vital activities is provided (Hoşsu et al., 2001). Mostly, the pollution of the environment in which the fish lives or the stress factor that occurs due to any reason causes the muscle activity in the fish to increase. Accordingly, the amount of blood glucose increases (Başusta, 2005). It has been reported that although the blood glucose level of fish rises suddenly after feed intake, it needs a long time to decrease to the same level again and is also affected by heavy metals and feed composition (Erdoğan et al., 2000; Y1ldırım et al., 2000; Şahan \& Cengizler, 2003).

\section{CONCLUSION}

In this study, the effects of zeolite on the accumulation of copper in fish and its toxicity on some blood parameters were investigated by adding $1.5 \mathrm{mg} / \mathrm{L}$ and $50 \mathrm{mg} / \mathrm{L}$ zeolite to the aquatic environment with tilapias. The highest body weight gain was found in the zeolite treatment with $68.5 \%$ and the lowest in the control treatment with $37.0 \%$. This may be an indication that fish develop better in the presence of zeolite in the environment. The highest decrease in muscle tissue protein ratios was found in the copper group and the least decrease in the copper + zeolite group. This can be explained by the fact that zeolite added to water causes an improvement in the ratio of muscle tissue protein in fish exposed to copper. Liver copper accumulation decreased in copper + zeolite treatment compared to copper treatment, but this decrease was not statistically significant ( $\mathrm{p}>0.05$ ). This can be thought to be caused by differences in water quality $(\mathrm{pH}$, alkalinity, hardness and salinity), fish weights, copper exposure time, and concentrations of copper in water. Cholesterol level decreased in copper and copper + zeolite treatments throughout the trial. This situation may be caused by the copper in the environment. On the other hand, it increased during the trial in zeolite treatment. The statistical similarity between the copper + zeolite treatment and the control treatment at the end of the experiment can be explained by the adaptation of the fish to the environment. Although the cholesterol level gradually decreases in the copper + zeolite treatment with copper, the copper treatment is higher than the copper + zeolite treatment when the cholesterol level is examined regardless of the periods during the trial. From this situation, it can be concluded that zeolite facilitates the adaptation 
process of fish. The increase in the triglyceride level during the experiment in copper treatment may mean that the triglyceride, which is the main energy source of metabolism, cannot be used in the required amount, or it can be explained as the copper in the environment binds to the structure of some proteins and causes them to fail their functions. The decrease of triglyceride during the trial in the zeolite treatment may mean that the energy requirement in the presence of the zeolite is provided from the triglyceride, while the triglyceride level first increases and then decreases in the copper + zeolite treatment can be explained by the presence of adaptation to ambient conditions. Although the LDH level increased in all treatments throughout the trial, the control group increased the least, with the highest increase in the copper group. However, the fact that copper + zeolite treatment is lower than the groups exposed to copper and zeolite may be related to the adaptation process of the fish to the environment containing copper. The higher LDH in the zeolite and copper exposed groups over the other two treatments during the trial may indicate the presence of stress in both treatments. Because in addition to natural factors such as water quality, nutritional status and reproduction, it is reported that factors such as capture stress, anesthesia method, blood collection method can change the blood parameters of cold blooded animals. It is also known that the blood glucose level may vary between species (Aydin et al., 2000).

When the results of the research are evaluated, it can be said that the zeolite added to the water does not have an adverse effect on the development of tilapian fish exposed to copper in a non-lethal concentration. On the other hand, it can be said that in aquatic environments with copper pollution, zeolite can be used to support the removal of the pollution from the environment and also that aquaculture can be done in these environments without harming the health of the fish.

\section{ACKNOWLEDGEMENTS}

The authors would like to thank to Mustafa Kemal University for financially supporting this study (Project No: 04 M 1702).

\section{REFERENCES}

Akyurt, İ. (2004). Balık Besleme. Mustafa Kemal Üniversitesi Su Ürünleri Fakültesi Ders Kitapları No: 3, 226.
Alfın-Slater, R. \& Howton, D. (1993). Lipids, Chemistry, Biochemistry and Nutrition. Plemum Pub., N.Y.

Alı, A., Al-Ogaily, S.M., Al-Asgah, N.A. \& Gropp, J., (2003). Effect of Sublethal Concentrations of Copper on The Growth Performance of Oreochromis niloticus. Journal of Applied Ichthyology, 19, 183-188.

Atamanalp, M., Haliloğlu, H.İ., Ayık, Ö., Cengiz, M., Özdemir, N. \& Bektaş, S. (2003). Üç farklı çiftlikten elde edilen gökkuşağı alabalıkları (Oncorhynchus mykiss, Walbaum, 1792)'nın kan biyokimyası parametrelerinin karşılaştırılması. XII. Ulusal Su Ürünleri Sempozyumu, Elazığ, 238-240.

ATSDR. (2003). Agency For Toxic Substances And Disease Registry, http://www.atsdr.cdc.gov/toxfaq.html.

Aydın, S., Yıldırım, A. \& Erdoğan, O. (2000). Aras nehrinde yaşayan Capoeta Capoeta Capoeta (Güldenstaedt, 1772)' nın kan glikoz düzeyindeki aylık değişimler. Turkish Journal of Veterinary and Animal Sciences, 24, 523-528.

Başusta, A.G. (2005). Balık Hematolojisi ve Hematolojik Metodlar. (M. Karataş, Editör). Balık Biyolojisi Araştırma Yöntemleri. Nobel Yayın, 772, 498, Ankara.

Boyd, C.E. \& Tucker, C.S. (1998). Pond Aquaculture Water Quality Management. Alabama Agricultural Experiment Station, Auburn University, Alabama.

Bricknell, I.R., Bowden, T.J., Bruno, D.W., MacLachlan, P., Johnstone, R. \& Ellis, A.E. (1999). Susceptibility of Atlantic halibut, Hippoglossus hippoglossus (L.) to infection with typical and atypical Aeromonas salmonicida. Aquaculture, 175(1-2), 1-13.

Chen, A.C.Y., Wooster, G.A., Getchell, R.G., Bowser, P.R. \& Timmons, M.B. (2003). Blood chemistry of healthy, nephrocalcinosis-affected and ozonetreated tilapia in a recirculation system, with application of discriminant analysis. Aquaculture. 218, 89-102.

Chen, H., Li, J., Yan, L., Cao, J., Li, D., Huang, G.Y., Shi, W.J., Dong, W., Zhad, J., Ying, G.G., Zhong, H., Wang, Z., Huang, Y., Luo, Y. \& Xiea, L. (2020). Subchronic effects of dietary selenium yeast and selenite on growth performance and the immune and antioxidant systems in Nile tilapia Oreochromis niloticus. Fish and Shellfish Immunology, 97, 283-293.

Cicik, B. (2003). Cyprinus Carpio (L.)' da Bakırın Kas ve Karaciğer Dokularındaki Glikojen Stokları ile Serum Glukoz Düzeyi Üzerine Etkileri. XII. Ulusal Su Ürünleri Sempozyumu, Elazığ. 37-41.

Çoğun, H.Y. \& Kargın, F. (2019). Oreochromis niloticus'un solungaç dokusu iyon düzeyleri üzerine kurşunun etkisi. Journal of Anatolian Environmental and Animal Sciences, 4(1), 22-26.

Çoğun, H.Y. \& Kargın, F. (2020). Cyprinus carpio'da bakırın solungaç dokusunda birikimi ve $\mathrm{Na} / \mathrm{K}$ iyon düzeylerine etkisi. Journal of Anatolian 
Environmental and Animal Sciences, 5(3), 313317.

Duru, M. (2005). Yohimbe Bark (Pausinystalia yohimbe) ve Demir Dikeni (Tribulus terrestris) Ekstratlarının Etlik Civcivlerde Büyüme Performansı ve Vucut Bileşimi Üzerine Etkilerinin Araştırılması. Yüksek Lisans Tezi, Mustafa Kemal Üniversitesi, Hatay, 62s.

Erdoğan, O., Çiltaş, A. \& Türkmen, M. (2000). Karasu Irmağı'nda yaşayan tatlı su kefali (Leuciscus cephalus orientalis, Nordmann,1840)' nin kan glikoz düzeyi üzerine üreme ve su sıcaklığının etkisi. Doğu Anadolu Bölgesi IV. Su Ürünleri Seтроzуити, 113-122, Erzurum.

Fialkowskı, W. \& Newman, W.A. (1998). A Pilot Study of Heavy Metal Accumulations in a Barnacle From The Salton Sea, Southern California. Marine Pollution Bulletin, 36(2), 138-143.

Fırat, Ö. \& Şahin İnandı, A. (2016). Oreochromis niloticus'ta Civanın Biyokimyasal Toksisitesi ve $\mathrm{Bu}$ Toksisite Üzerine Zeolitin Koruyucu Etkisi. Turkish Journal of Aquatic Sciences, 31(2), 8695.

Gülyavuz, H. \& Ünlüsayın, M. 1(999). Su Ürünleri İsleme Teknolojisi. Şahin Matbaası, Ankara.

Hoşsu, B., Korkut, A.Y. \& Fırat, A. (2001). Balık Besleme ve Yem Teknolojisi I. Ege Üniversitesi Su Ürünleri Fakültesi Yayınları No: 50, Ders Kitabı Dizini No: 19, 295, İzmir.

James, R. \& Sampath, K. (2003). Removal of Copper Toxicity by Zeolite in Java Tilapia Oreochromis mossambicus (Peters). Bulletin Environmental Contamination \& Toxicolology, 71, 1184-1191.

Kalay, M. \& Erdem, C. (2003). Tilapia nilotica' da Kadmiyum Birikiminin Total Protein Düzeyine Etkisi. Turkish Journal of Veterinary and Animal Sciences, 27, 1367-1374.

Mutlu, E., Aydın, S., Demir, T. \& Yanı, T. (2016). Effect of Zeolite and Copper Sulfate, Administered Alone and in Combination on the Biochemical Components of Blood Serum of Common Carp, Cyprinus carpio. Pakistan Journal of Zoology, 48(6), 1857-1863.

Oğuztürk, O., Çiftçi, N. \& Cicik, B. (2018). Effects of natural adsorbent clinoptilolite on some hematological parameters of Cyprinus carpio. Ege Journal of Fisheries and Aquatic Seciences, 35(4), 455-462.

Park, J.B., Lee, S., H., Lee, J.W. \& Lee, C.Y. (2002). Lab Scale Experiments for Permeable Reactive Barriers against Contaminated Groundwater with Ammonium and Heavy Metals Using Clinoptilolite. Journal of Hazardous Materials, 95, 65-79.

Straus., D.L. (2003). The Acute Toxicity of Copper to Blue Tilapia in Dilutions of Settled Pond Water. Aquaculture, 219, 233-240.

Şahan, A. \& Cengizler, İ. (2003). Seyhan Nehri (Adana Kent İçi Bölgesi)' nde Yaşayan Adi Sazan (Cyprinus carpio, Linnaeus, 1758) ve Biylkl1 Balık (Barbus rajanorum, Heckel, 1843)' ta Bazı
Hematolojik Parametrelerin Belirlenmesi. XII. Ulusal Su Ürünleri Sempozyumu, Elazığ. 196201.

Tepe, Y., Akyurt, İ., Ciminli, C., Mutlu, E. \& Çalışkan, M. (2004). Protective effect of clinoptilolite on lead toxicitiy in common carp (Cyprinus Carpio). Fresenius Environmental Bulletin, 13(7), 639642.

Türkman, A., Aslan, Ş. \& Ege, İ. (2001). Doğal Zeolitlerle Atıksulardan Kurşun Giderimi (Lead Removal From Wastewaters By Natural Zeolites). DEÜ Mühendislik Fakültesi Fen ve Mühendislik Dergisi, 3(2), 13-19.

Türkmen, M., Erdogan, O. \& Haliloğlu, H.í. (2000). Karasu Irmağı'nın Aşkale Mevkii'nden Capoeta capoeta umbla (Heckel,1843) Balığının Kan Glikoz Düzeyi Üzerine Bir Araştırma, Doğu Anadolu Bölgesi IV. Su ürünleri Sempozyumu, 251-260, Erzurum.

Türkmen, M. \& Öğütçü, B. (2020). Assessment of Heavy Metals in Selected Fish Species from Markets in the Black Sea Region of Turkey. Journal of Anatolian Environmental and Animal Sciences, 5(4), 636-639.

Ünlü, E. \& Gümgüm, B. (1993). Concentrations of Copper and Zinc in Fish and Sediments From The Tigris River in Turkey. Chemosphere, 26(11), 2055-2061.

Van Heerden, D., Tiedt, L.R. \& Vosloo, A. (2004). Gill Damage in Oreochromis mossambicus and Tilapia sparrmanii After Short-Term Copper Exposure. International Congress Series, 1275, 195-200.

Watson, C. \& Yanong R.P.E. (2002). Use of Copper in Freshwater Aquaculture and Farm Ponds. Department Of Fisheries and Aquatic Sciences, Florida Cooperative Extension Service, Institute Of Food And Agricultural Sciences, University Of Florida.

Yazkan, M., Özdemir, F. \& Gölükçü, M. (2002). Antalya' da Avlanan Bazı Balık Türlerinde $\mathrm{Cu}$, $\mathrm{Zn}, \mathrm{Pb}$ ve $\mathrm{Cd}$ İçeriği. Turkish Journal of Veterinary and Animal Sciences, 26, 1309-1313.

Yıldırım, A., Türkmen, M. \& Altuntaş, İ. (1999). The seasonal variation in blood glucose levels in barbel, Barbus plebejus escherichi (Steindachner, 1897), living in Çoruh Basin-Oltu Stream. Turkish Journal of Veterinary and Animal Sciences, 23, 373-378.

Yıldırım, A., Türkmen, M. \& Altuntaş, İ. (2000). Çoruh Nehri Oltu Çayı'nda Yaşayan Capoeta tinca (Heckel, 1843)'nın Kan Glikoz Düzeyindeki Aylık Değişimler. Turkish Journal of Biology, 24, 49-56. 